\title{
Nature-Based Solution along High-Energy Eroding Sandy Coasts: Preliminary Tests on the Reinstatement of Natural Dynamics in Reprofiled Coastal Dunes
}

\author{
Bruno Castelle ${ }^{1, * \mathbb{C}}$, Quentin Laporte-Fauret ${ }^{1}$, Vincent Marieu ${ }^{1} \mathbb{D}$, Richard Michalet ${ }^{1}$, \\ David Rosebery ${ }^{2}$, Stéphane Bujan ${ }^{1}$, Bertrand Lubac ${ }^{1}{ }^{\circledR}$, Jean-Baptiste Bernard ${ }^{3}$, \\ Alexandre Valance ${ }^{3}$, Pascal Dupont ${ }^{4}$, Ahmed Ould El Moctar ${ }^{5}$ and Clément Narteau ${ }^{6}$ (D) \\ 1 University Bordeaux, CNRS, UMR EPOC, 335615 Pessac, France; \\ quentin.laporte-fauret@u-bordeaux.fr (Q.L.-F.); vincent.marieu@u-bordeaux.fr (V.M.); \\ richard.michalet@u-bordeaux.fr (R.M.); stephane.bujan@u-bordeaux.fr (S.B.); \\ bertrand.lubac@u-bordeaux.fr (B.L.) \\ 2 Office National des Forêts, 75012 Paris, France; david.rosebery@onf.fr \\ 3 University Rennes, CNRS, IPR (Institut de Physique de Rennes), UMR 6251, 35700 Rennes, France; \\ jean-baptiste.besnard@univ-rennes1.fr (J.-B.B.); alexandre.valance@univ-rennes1.fr (A.V.) \\ 4 University Rennes, INSA, 35700 Rennes, France; Pascal.Dupont@insa-rennes.fr \\ 5 University Nantes, CNRS, UMR 6607, 44306 Nantes, France; ahmed.ouldelmoctar@univ-nantes.fr \\ 6 University Paris, Institut de Physique du globe de Paris, CNRS, 75005 Paris, France; narteau@ipgp.fr \\ * Correspondence: bruno.castelle@u-bordeaux.fr; Tel.: +33-540002450
}

Received: 28 October 2019; Accepted: 25 November 2019; Published: 28 November 2019

\begin{abstract}
This paper describes a large-scale experiment designed to examine if reinstating natural processes in the coastal dune systems of Southwest France can be a relevant nature-based adaptation in chronically eroding sectors and a nature-based solution against coastal hazards, by maintaining the coastal dune ecological corridor. An experiment started in late 2017 on a 4-km-long stretch of coast at Truc Vert, where experimental notches were excavated and intensively monitored in the incipient and established foredunes. Preliminary results indicate that most of the excavated notches did not develop into blowout. Only the larger elongated notches subsequently excavated in the established foredune in 2018 showed evidence of development, acting as an effective conduit for aeolian landward transport into the dunes. All notches were found to have a statistically significant impact on vegetation dynamics downwind, even those that did not develop. The area of bare sand landward and within the elongated notches notably increased implying a loss of vegetation cover during this first stage of development. Observations of a nearby coastal dune system that has been in free evolution over the last 40 years also indicate that, although the dune migrated inland by more than $100 \mathrm{~m}$, it is now mostly made of bare sand. Further work is required to explore if and how dunes maintained as dynamic systems can become an efficient nature-based solution along this eroding coastline.
\end{abstract}

Keywords: coastal dunes; erosion; resilience; vegetation dynamics; blowouts; nature based solution; coastal management; photogrammetry

\section{Introduction}

In a context of climate change and population growth, balancing protection/restoration of ecosystem services, development and population safety is one of the greatest challenges for future generations. In this framework, the coastal zone is a major interface that is becoming increasingly topical and politically sensitive worldwide in a context of widespread erosion [1], increasing 
anthropogenic pressures, e.g., urban expansion, recreational development [2], and climate change, e.g., sea level rise and increase in storminess [3,4]. Over the last decade, there has been a growing scientific and engineering interest in exploring how natural processes can provide management solutions to resolve the degradation and/or vulnerability of coastal environments [5], primarily to erosion and flooding hazards. These nature-based solutions include, but are not restricted to, coral reef restoration, e.g., [6]; or artificial reef construction, e.g., [7]; dissipating wave energy further offshore; flood defence solutions such as oyster reefs, salt marshes and mangroves; and mega sand nourishment [8].

Sandy coasts, which represent approximately $31 \%$ of the world's ice-free shoreline [9], are particularly exposed and vulnerable to erosion and have long been preferred sites for human settlements and tourism. Most beaches are backed by coastal dunes, with the composite beach-dune system acting as both a natural flooding protection to the hinterland and a buffer against eroding storm waves. Coastal dunes also nest unique and fragile ecosystems. With the loss of biodiversity being now a major concern, e.g., [10,11], coastal dunes also have high ecological value under imminent erosion threat.

During the 20th century, most coastal dunes on developed shores have been managed for different reasons, e.g., [12]. These include preventing sand encroachment into settlements and onto agricultural land, and/or to minimising erosion and submersion hazards. Therefore, coastal dunes have often been designed as prominent alongshore-uniform features (Figure 1a). However, variations in topography within dunes provide differences in exposure to overwash, flooding, wind, sediment transport and salt spray, a variability inextricably linked to the variety of microhabitats and landscape diversity (Figure 1b). Therefore, in some regions of the world, actively managed coastal dunes, sometimes so-called "dune dykes" [13], lost the ecosystem values and services offered by natural coastal dunes through a reduction in vegetation dynamics and natural community diversity [14].
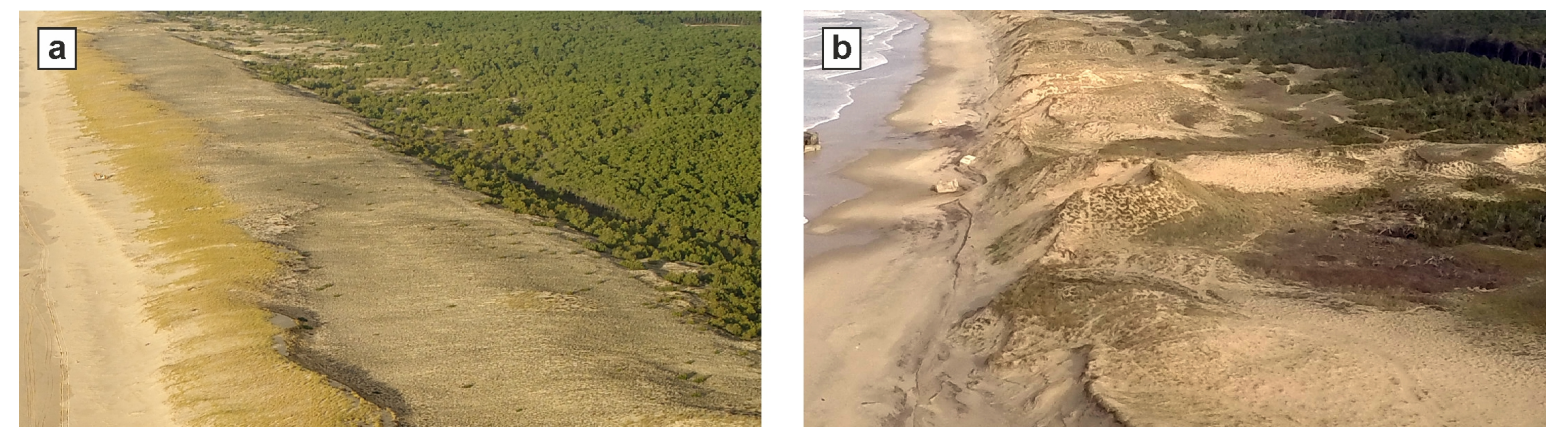

Figure 1. Aerial photographs in Southwest France of (a) a reprofiled coastal dune designed as an alongshore-uniform feature with limited natural community diversity at Truc Vert, contrasted with (b) an alongshore-variable dune field with more natural community diversity at Anse du Gurp, Southwest France (Ph. V. Marieu).

In certain coastal dune environments, greater morphological and community diversity may result in greater resilience, e.g., [15]. When located in chronically eroding sectors, managed prominent dunes can be severely eroded, with high erosion scarp preventing further natural beach-dune sediment exchange (left-hand panels in Figure 2). Such coastal dune may progressively narrow (Figure 2a) and can eventually disappear (Figure 2b,c), resulting in greater exposure of the hinterland to submersion and overwash. In contrast, coastal dunes maintained as dynamic systems (right-hand panels in Figure 2) are potentially more resilient than fixed dunes. In such situations, beach-dune sediment exchanges are maintained (Figure $2 \mathrm{~d}$ ) and the entire coastal dune system has the ability to migrate landward, so that the ecological corridor is maintained (Figure 2e,f). However, whether it can also reduce coastal erosion and shoreline recession rate is virtually unknown. In some regions of the world, natural-free coastal dunes can be essentially made of bare sand with no or little community abundance and/or diversity, as increasing physical disturbance in stressful environments is known to negatively impact plant species diversity [16,17], as shown in [18] in the French Atlantic coastal dunes. Between 
the two extreme situations shown in Figure 2, a solution may rely on achieving a subtle balance where the coastal dune may require human adjustments to "survive" using the so-called "controlled dynamism" strategy [19]. This balance has never been studied quantitatively, mostly because of the lack of both an integrative (physics, biology and management) approach and landscape-scale high-resolution data. More natural and mobile dunes could arise as a relevant nature-based adaptation to coastal erosion, allowing the beach and dune systems to move landward and persist in response to coastal erosion. It may also reduce exposure to submersion and overwash during severe storm, and potentially reduce erosion rates, therefore acting as an efficient nature-based solution against coastal hazards in some regions of the world. Addressing the sustainability and efficiency of such solutions requires the development of innovative and often costly experiment based on multidisciplinary and transdisciplinary approach as well as long-term monitoring.
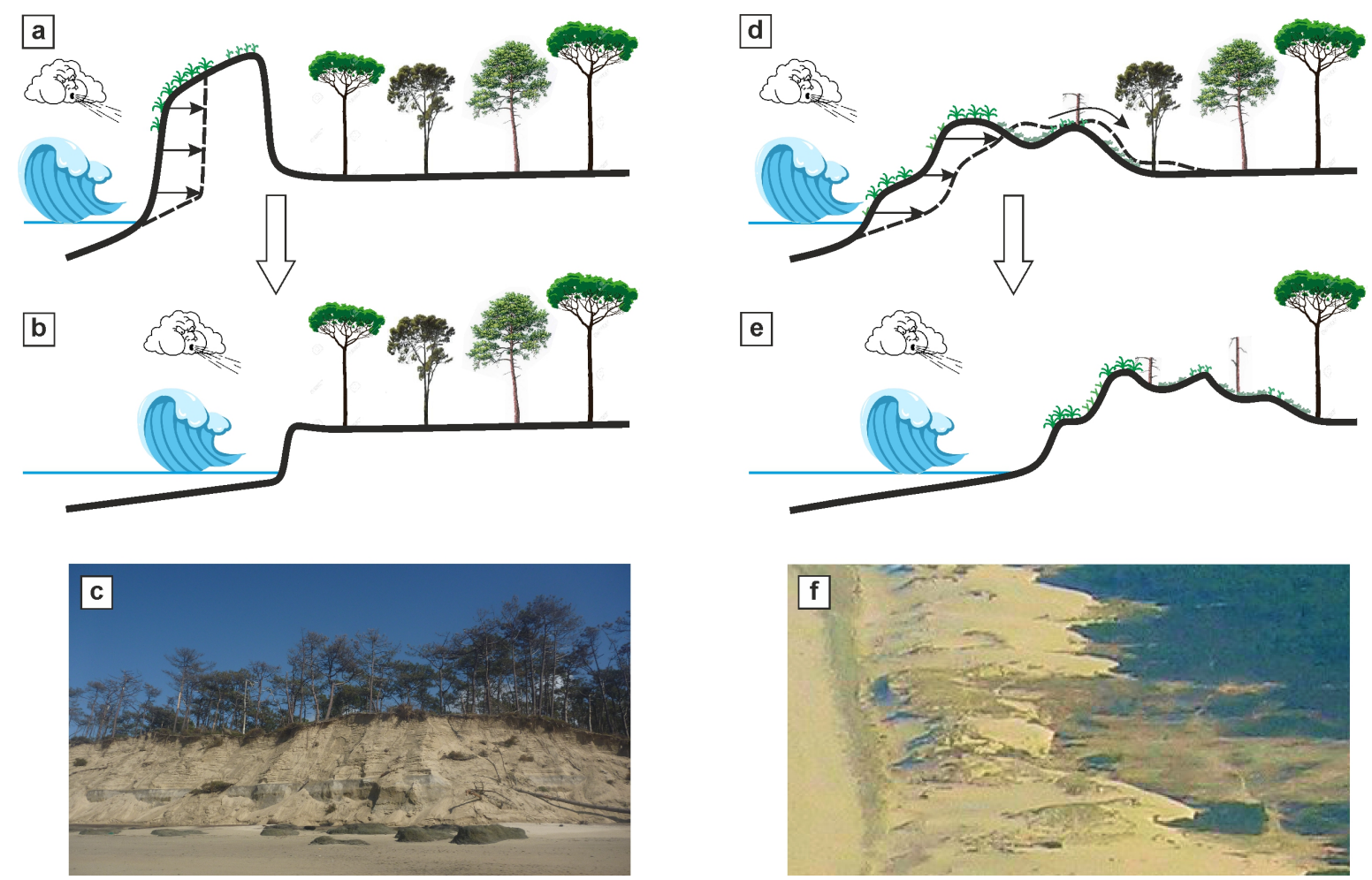

Figure 2. Schematics of coastal dune change in a chronic erosion sector for $(\mathbf{a}-\mathbf{c})$ managed prominent dunes and $(\mathbf{d}-\mathbf{f})$ coastal dunes maintained as more dynamic systems, which are suspected to favour resilience.

The southwest coast of France hosts approximately $300 \mathrm{~km}$ of sandy beaches backed by high and wide coastal dunes that have been largely mechanically reprofiled in the 1970s and 1980s. Some sectors are severely eroding [20], with progressively narrowing coastal dunes. Reinstating some natural processes and beach-dune sediment exchanges therefore needs to be explored to (i) maintain this ecological corridor and (ii) serve as an efficient nature-based solution against coastal hazards. In this paper, we present preliminary results from a research project building on an in-depth collaboration between scientists (physicists, geomorphologists and ecologists) and stakeholders, looking at beach-dune sediment exchanges, vegetation dynamics and natural community diversity. This experiment aims at providing new fundamental and practical insights into coastal dune resilience in order to improve coastal dune management strategies. Section 2 provides a description of the Gironde coast, Southwest France, and of the experimental set-up at Truc Vert beach, which was designed to reinstate natural processes in the reprofiled coastal dune through the excavation of notches in the foredune. Preliminary results on the monitoring of coastal morphology and vegetation dynamics are shown in Section 3 and are further discussed in Section 4. 


\section{Field Site and Experimental Set-Up}

\subsection{The Gironde Coast}

The Gironde coast is located in Southwest France and covers approximately $135 \mathrm{~km}$ of sandy surf beaches (Figure 3a). It extends from the Medoc peninsula in the north to Biscarrosse border in the south. It can be divided into two sectors separated by the Arcachon Lagoon inlet: (1) a 110-km-long northern sector composed of open sandy beaches dominantly facing W-WNW, with more variability in the north in Soulac area and in the south at the tip of the Cap Ferret sandspit, and (2) a 25-km-long southern sector composed of surf beaches facing NW to W, which is largely influenced by the Arcachon Lagoon inlet.

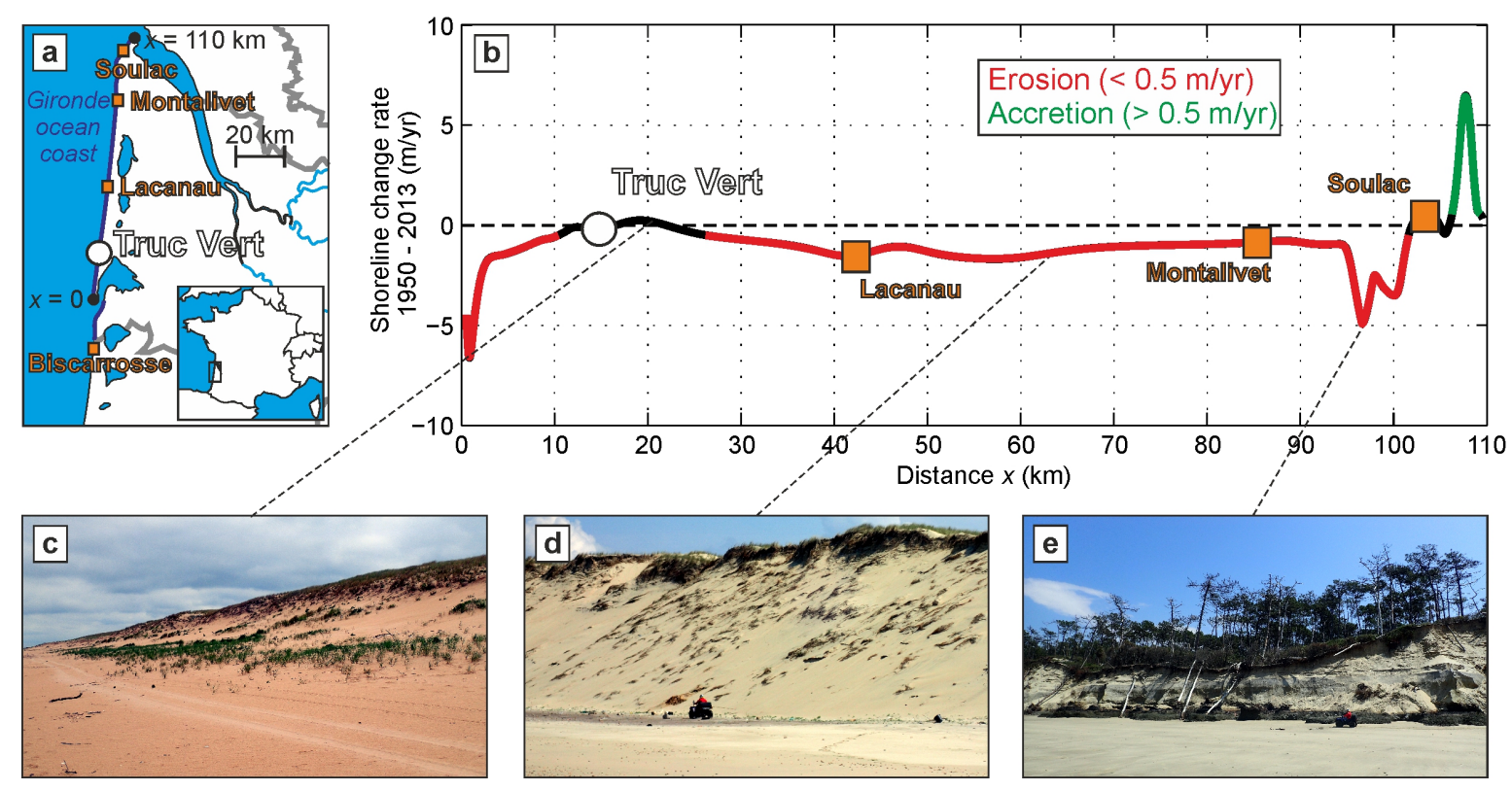

Figure 3. (a) Location map of the Gironde coast; (b) chronic erosion rates along the 110-km-long northern sector modified after [20] and (c-e) coastal dune landscape at representative sectors on 21 May 2019 (Ph. B. Castelle).

Beaches are mesotidal and primarily composed of fine to medium quartz sand. The most frequent and strongest wind events are onshore-directed from the WSW-WNW sector. The wave climate is energetic with a dominant $\mathrm{W}$ to $\mathrm{NW}$ incidence. It is strongly seasonally modulated with the monthly-averaged significant wave height ranging from $1.11 \mathrm{~m}$ in July with a dominant W-NW direction to $2.4 \mathrm{~m}$ in January with a dominant $\mathrm{W}$ direction [21]. Winter wave activity and storms show a strong interannual variability, with moderate winters alternating with extreme winters characterised by spatial and temporal storm clustering [22]. Such interannual variability is enforced by natural modes of climate variability, particularly the West Europe Pressure Anomaly [23], with a significant increase in winter-mean wave height, variability and periodicity over the last 70 years [24]. The dominant W-NW wave climate drives a net southerly longshore drift ranging between 100 and $350 \times 10^{3} \mathrm{~m}^{3} /$ year across the entire Gironde coast [25], locally reversing near Soulac and north of Biscarrosse where the coast faces NW.

All the sandy beaches of the Gironde coast are backed by high and wide coastal dunes, except along the small coastal resorts of Soulac, Montalivet and Lacanau (Figure 3a,b). Coastal dunes have disappeared along a sector covering approximately $4 \mathrm{~km}$ of coastline south of Soulac, where chronic erosion over the last 70 years has exceeded $2-3 \mathrm{~m} /$ year (Figure $3 \mathrm{~b}, \mathrm{e}$ ). In some other sectors, typically where chronic erosion is $\sim 1-2 \mathrm{~m} /$ year, e.g., between Lacanau and Montalivet, the coastal dune is locally 20-30 m wide with up to 10-15 m high dune scarp (Figure 3d). In comparison with the winter of 2013/2014, which was the most energetic winter along most of the Atlantic coast of Europe [22] with local dune erosion exceeding $30 \mathrm{~m}[21,26,27]$, this means that severe winter could deplete the 
coastal dune system and leave the coastal forest directly exposed to marine erosion. At our field site of Truc Vert, alongshore variable coastal dune erosion enforced by the alongshore variability in depth of the outer sandbar was observed, with coastal dune retreat peaking at approximately $20 \mathrm{~m}$ in the megacusp embayment [26]. Since then, the coastal dune has been mostly recovering at Truc Vert with the development of an incipient foredune [21], although coastal dune and shoreline recovery is highly variable along the Gironde coast $[27,28]$.

Note that the contemporary coastal dune morphologies and response along the Gironde coast is largely inherited from a long history of anthropogenic works. The coastal dune system was first established in the nineteenth century to protect the forest, with extensive reprofiling and gourbet and marram planting. The coastal dune subsequently suffered severe erosion from some outstanding winter storms in the 1910s and 1920s, and the Second World War when the coastal dunes were restricted areas used as a source of aggregate for the Nazis. Until the early 1960s, the coastal dunes were largely dissected by blowouts and hollowed out as gullies. The Office National des Forêts (ONF) undertook extensive renovation between the 1960s and 1980s using large-scale mechanical aid and vegetation planting [29,30]. An engineering profile was imposed (see Figure 4a for Truc Vert area) with subsequent intensive marram planting (Figure $4 \mathrm{~b}-\mathrm{e}$ ). Since the $80 \mathrm{~s}$, the coastal dune system showed little natural evolution compared with the overall scale of the system. Unpublished results based on ground penetrating radar measurements indicate that most of the reprofiled coastal dune slightly evolved before becoming fixed as the current transition/grey dune shown in Figure 5b. In the meantime, a foredune ridge has been building and slowly migrating over the grey dune over the last decades (around the cross-shore distance of $50 \mathrm{~m}$ in Figure 4a), which is where most of the morphological changes currently occur. Figure 4 a shows the overall current coastal dune profile superimposed onto the engineering profile, also revealing a positive sediment budget of the coastal dune system at this site.
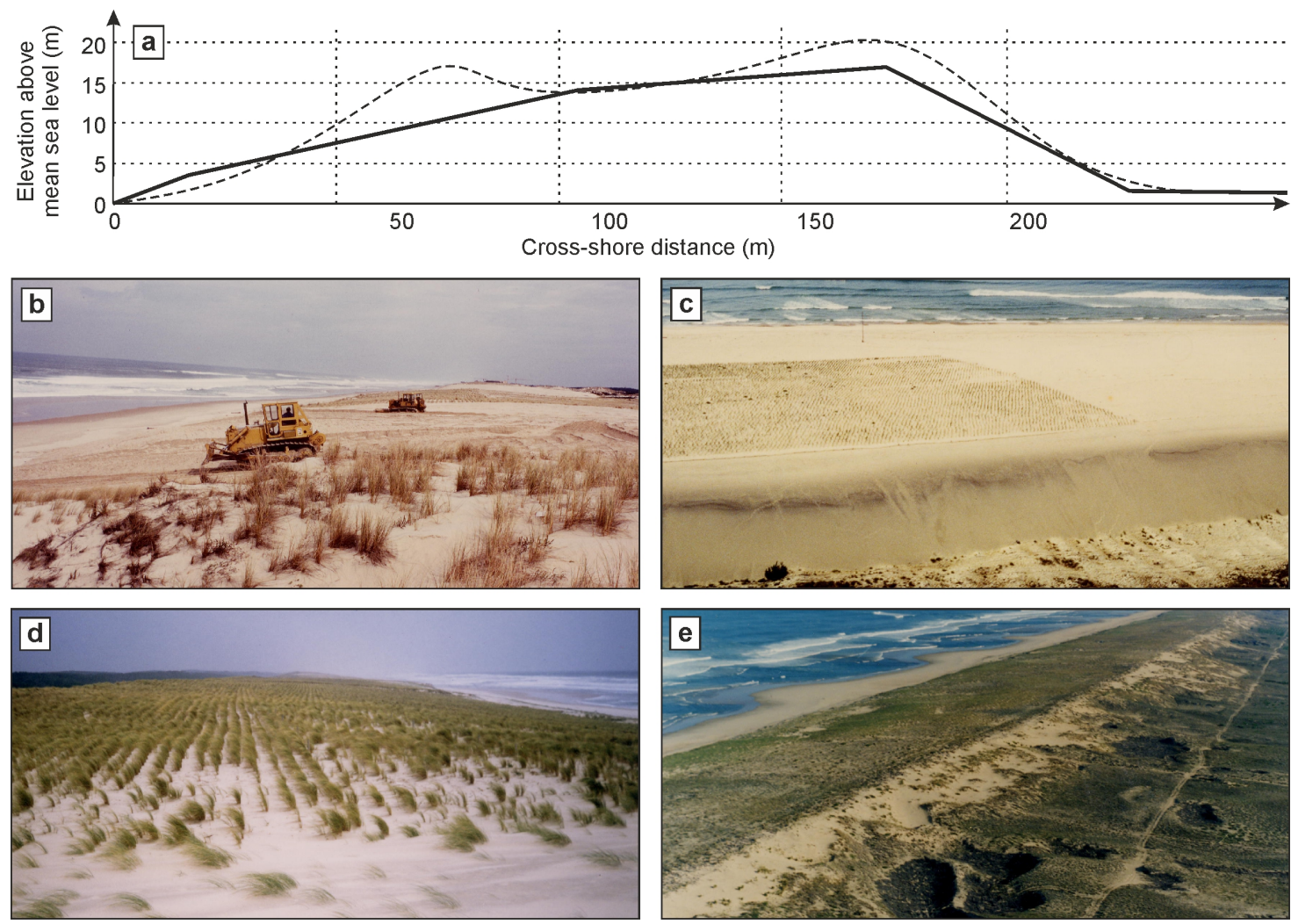

Figure 4. (a) Schematic of the mechanically reprofiled coastal dune near Truc Vert (thick solid line) with superimposed overall current profile (thin dashed line). Photographs showing (b) the mechanical reprofiling, subsequent (c) partial and (d) completed marram planting and resulting calibrated coastal dune in the early 1980s. Photos @ONF 


\subsection{Truc Vert Experimental Set-Up}

In November 2017, a large-scale project was established to make fundamental progress in the understanding of the interactions between aeolian, marine and biotic processes driving coastal dune evolution. Although the project also involves well-adapted mesoscale modelling techniques [31] and satellite remote sensing, the core of the project was the design of an ambitious experiment at Truc Vert beach. Monitoring morphological changes, aeolian sand transport and vegetation dynamics, the experiment aimed at reinstating natural processes in an artificially reprofiled coastal dune system and at monitoring morphological changes, aeolian sand transport and vegetation dynamics.

This experiment was carried out on a 4-km-long stretch of Truc Vert beach extending approximately $300 \mathrm{~m}$ in the cross-shore to cover the entire beach-dune system (Figure 5). This $4 \mathrm{~km}$ sector was divided into four blocks where experimental notches were excavated. Each experimental block was separated from each other by domains of a few hundreds of metres where no mechanical work was performed. In each experimental block, two large experimental notches were excavated in December 2017 (Figure 5a): one located in the incipient foredune, and the other in the established foredune. These notches were excavated to increase the landward transport of sand and dune mobility that was reduced after the severe scarping of the foredune during the 2013/2014 winter [26]. The number of notch configurations was limited to ensure spatial replication for the vegetation dynamics statistical analysis. Their overall shape was designed together with coastal dune stakeholders to mimic incipient blowouts that can form along this stretch of coast under severe windstorms. Their size was limited by the coastal dune stakeholders. The volume of the notches varied from $10.5 \mathrm{~m}^{3}$ to $96.7 \mathrm{~m}^{3}$ with a mean of $56.7 \mathrm{~m}^{3}$, and their depth from $0.8 \mathrm{~m}$ to $1.6 \mathrm{~m}$ with a mean of $1.2 \mathrm{~m}$. Instead of developing into natural blowouts, the notches excavated in December 2017 were systematically partially infilled (see Section 3). Therefore, immediately prior to the subsequent winter (2018/2019), in November 2018, new notches were excavated. Incipient foredune notches were excavated at about the same location, whereas the established foredune notches were excavated in the alignment of the former notches and extended further inland. The volume excavated was larger than in 2017, ranging from $74.1 \mathrm{~m}^{3}$ to $140.1 \mathrm{~m}^{3}$ with a mean of $101.8 \mathrm{~m}^{3}$, and with depth ranging from $1.5 \mathrm{~m}$ to $2.5 \mathrm{~m}$ with a mean of $2.1 \mathrm{~m}$. The established foredune notches were reshaped as elongated troughs across the established foredune crest (Figure 5d). This new shape was designed together with local dune stakeholders to promote sediment transport from the beach to the back of the dune. 

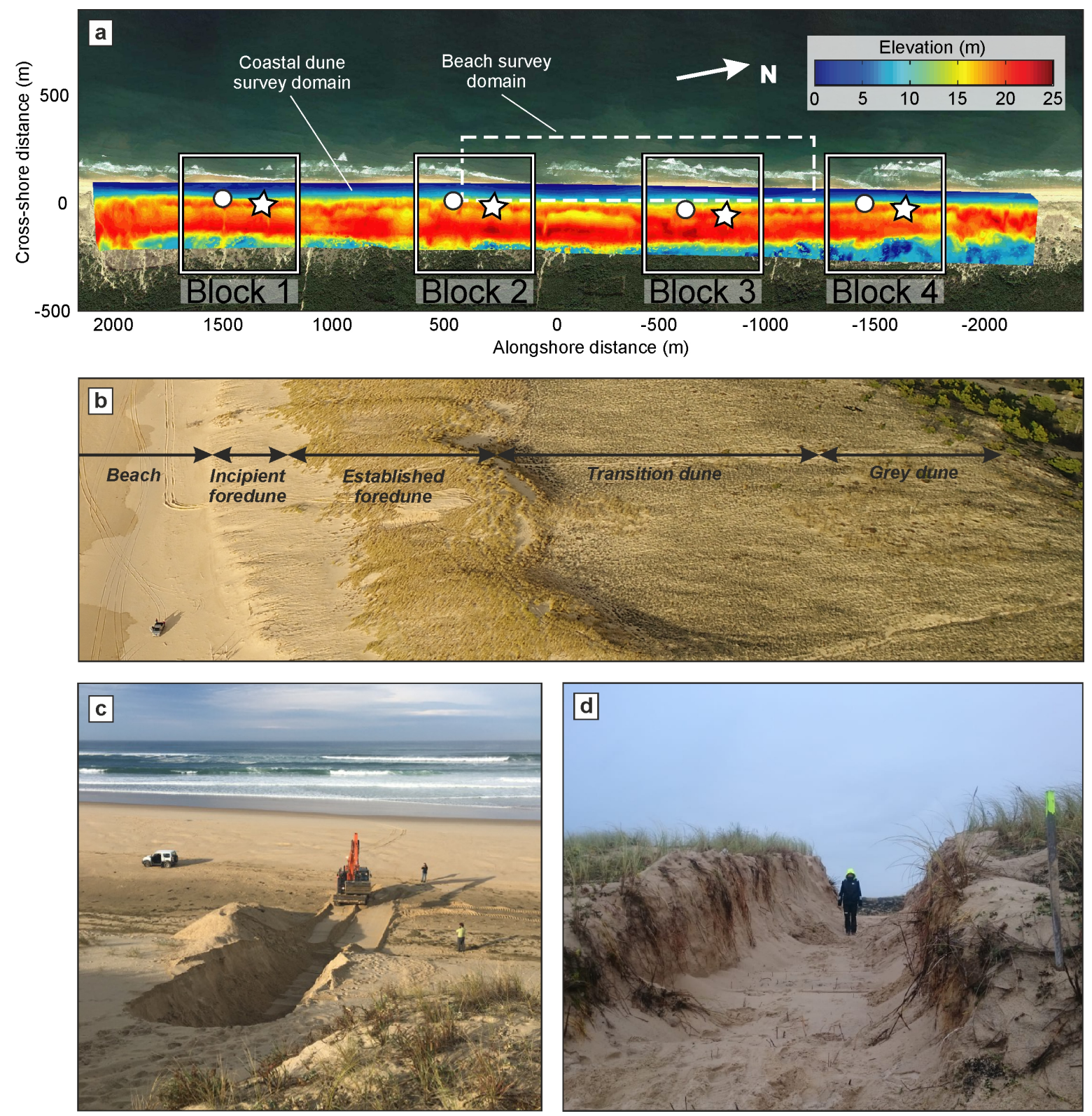

Figure 5. (a) Truc Vert experimental site. A digital surface model (DSM) of the coastal dune system inferred from photogrammetry using a low-cost unmanned aerial vehicle (UAV) is coloured, and the dashed white rectangle shows the beach area which is surveyed semi-monthly with a differential global positioning system (DGPS)-equipped ATV. The solid rectangles indicate the experimental blocks (1-4) where notches were excavated in the incipient foredune (circles) and in the established foredune (stars). (b) Truc Vert beach landscape with indication of the typical coastal dune compartments and with the 4-wheel drive making the scale. (c) Incipient foredune notch excavated on 5 November 2018 (Ph. B. Castelle). (d) Established foredune 2.5-m-deep notch with Q. Laporte-Fauret made the scale (Ph. V. Marieu).

\subsubsection{Topographic Surveys}

Topographic beach surveys of Truc Vert beach are sampled every two weeks at spring low tide using a differential global positioning system (DGPS)-equipped ATV. Although the alongshore coverage of the topographic surveys has varied over the years, it has been stabilised to approximately $1500 \mathrm{~m}$ since 2012 (Figure 5). Such a large alongshore coverage was designed to encompass approximately 3-4 inner-bar rip-channel wavelengths and to further compute reliable alongshore-averaged values such as shoreline position and beach volume. Anisotropic kriging 
interpolation is performed to obtain a digital elevation model (DEM) on a regular grid with an alongshore and cross-shore mesh size of $20 \mathrm{~m}$ and $2 \mathrm{~m}$, respectively. For a detailed description of the beach survey dataset, the reader is referred to [32].

To survey the coastal dune, a low-cost and lightweight UAV-camera photogrammetry technique was used. Accurate (root-mean-squared vertical error $<0.1 \mathrm{~m}$ ) and high-resolution $(0.1 \mathrm{~m})$ digital surface models (DSMs) can be inferred routinely on large spatial scales (few kilometres of coastal dune), using a well-designed spatial distribution of permanent ground control points [33]. Such approach allows depicting subtle morphological changes driven by both marine and aeolian processes [33]. Coastal dune surveys are performed quarterly, with additional surveys after severe storm events. Coastal dune surveys were also performed immediately before and after the notches were excavated in December 2017 and November 2018.

\subsubsection{Vegetation Surveys}

Plant community composition and abundance was surveyed quarterly along cross-shore transects extending from the beach to the grey dune (Figure 6). In each experimental, block two transects were aligned with the notches, with two additional transects located approximately $100 \mathrm{~m}$ southward of the notches. Each transect was composed of 13 sampling points along the different coastal dune compartments (incipient foredune, foredune, transition dune and grey dune in Figure $5 b$ ) according to Figure 6a. In each nonexperimental block, one cross-shore transect located approximately in the middle of the block was surveyed, for a total of 260 sampling points within the $4 \mathrm{~km}$ beach-dune domain. At each sampling point, a 1- $\mathrm{m}^{2}$ quadrat with a mesh size of $0.2 \mathrm{~m}$ was deployed to monitor the composition and abundance of vegetation species. Only plants with their vertical projection located within a circle of approximately $0.03-\mathrm{m}$ diameter of a grid point, defined as the intersections of two lines, were taken into account. An abundance of 0.5 was assigned to species present in the quadrat but outside of these intersections. Additional environmental parameters were measured such as sand elevation, litter decomposition, wind abrasive potential and grain size.

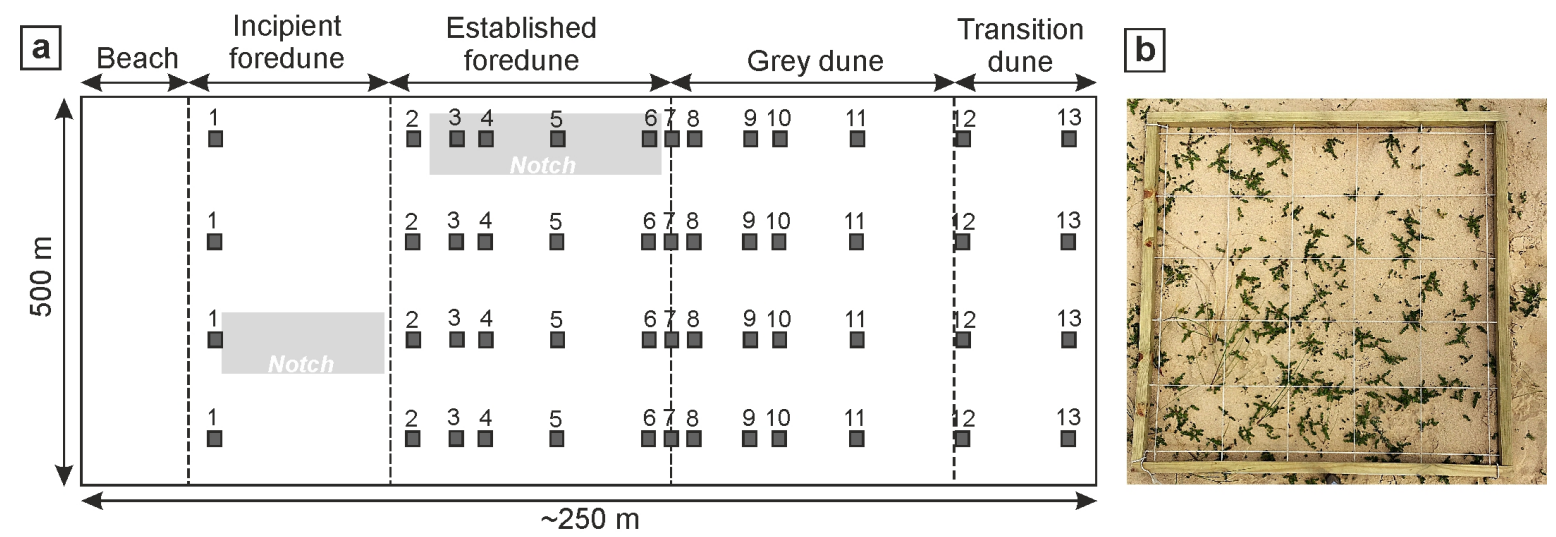

Figure 6. (a) Schematic of the four transects of vegetation plots (squares with numbers) within a given experimental block, with experimental notch locations indicated by the light grey areas. (b) Picture of a $1-\mathrm{m}^{2}$ quadrat used to survey plant community composition.

\section{Preliminary Results}

The notches excavated in December 2017 did not transform into blowouts. Instead, the incipient foredune notches progressively infilled even during the winter, whereas the notches excavated in the established foredune primarily infilled later and at a slower rate during spring and summer. Despite the notches not developing into blowouts with even slight vegetation regrowth in some of the notches, a recent effort showed that the notches had a statistically significant impact on downwind vegetation dynamics [34]. In brief, vegetation composition was primarily controlled by the distance from the mean sea level shoreline, the alongshore location within the $4 \mathrm{~km}$ sector and the presence of a nearby 
notch. Given the limited morphological changes, we provide below a preliminary description of coastal dune changes after the new notches have been excavated in November 2018.

Figure 7 shows the morphological changes of the most northern elongated notches excavated in the established foredune in November 2018. The notch extended approximately $5 \mathrm{~m}$ and $50 \mathrm{~m}$ in the longshore and cross-shore directions, respectively, with a maximum depth of approximately $2.5 \mathrm{~m}$ (Figure 7c). The notch remained nonvegetated during the subsequent 7 months, and the area of bare sand landward of the notch also slightly increased with time. Large morphological changes were also observed as shown by the cumulative changes in Figure $7 \mathrm{~m}$. We can observe the levelling and retreat of the lateral walls because of the avalanching and slumping of material onto the notch floor. This overall erosion pattern is readily symmetric, although the more short-term changes appear asymmetric (e.g., Figure 7k) owing to the onshore shore-oblique wind climate, which can come from the SW or the NW. The most seaward central part of the notch floor eroded by almost $1 \mathrm{~m}$, whereas the most landward part accreted by more than $1 \mathrm{~m}$. A thin depositional lobe is also observed. The overall positive sand budget landward of the established foredune crest implies that the notch has been acting as an effective conduit for landward aeolian transport, with formation of new aeolian landforms, with this notch representative of the three other ones.

In contrast with the established foredune notches, the incipient foredune notches did not develop (not shown), which is similar to the behaviour of the incipient foredune notches previously excavated in December 2017. This is because the coastal dune at Truc is still recovering from the outstanding winter of 2013/2014, during which $200 \mathrm{~m}^{3} / \mathrm{m}$ was lost from the system, being approximately equally distributed between the beach and the dune [21]. Figure 8 shows the time series of winter WEPA, which is a proxy for winter storminess in Southwest France [23], and the concurrent beach volume evolution over the 2005-2019 period. Results show that the beach lost approximately $100 \mathrm{~m}^{3} / \mathrm{m}$ of sand during the 2013/2014 winter, but fully recovered within two years, in contrast with the coastal dune [21]. Therefore, since spring-summer 2015, the beach is wider providing large sediment supply to the incipient foredune that has been growing since then (see also Figure $7 \mathrm{~m}$ ). As a result, the notches excavated in the incipient foredune in both December 2017 and November 2018 were rapidly filled with the wind-blown sand from the beach, particularly during the winter months when the dominant wind is onshore-directed.

Given the importance of the small notches excavated in December 2017 on vegetation dynamics downwind, the larger notches excavated in November 2018 are under close observation. At the time of writing this paper, the vegetation dynamics has not been fully analysed; however, a visual inspection of the coastal dune and photographs shows that, despite the low-wind winter of 2018/2019, there is a clear signature of the notches on the vegetation abundance and composition downwind. For example, Figure 9 shows clear change in vegetation abundance and composition landward of an established foredune notch. The area of bare sand landward of the notches increased markedly as the deposition lobe advances downwind into the vegetation of the transition dune. However, further downwind, the slight sand burial causes the vegetation cover to readily increase, with vegetation regrowth primarily at the outline of the depositional lobe. A closer inspection of the photos also indicates the presence of beach grass nearby the deposition lobe, suggesting that some wind-blown beach sand and grass propagule have been deposited on the landward side of the foredune though the excavated notches (Figure 9f). 

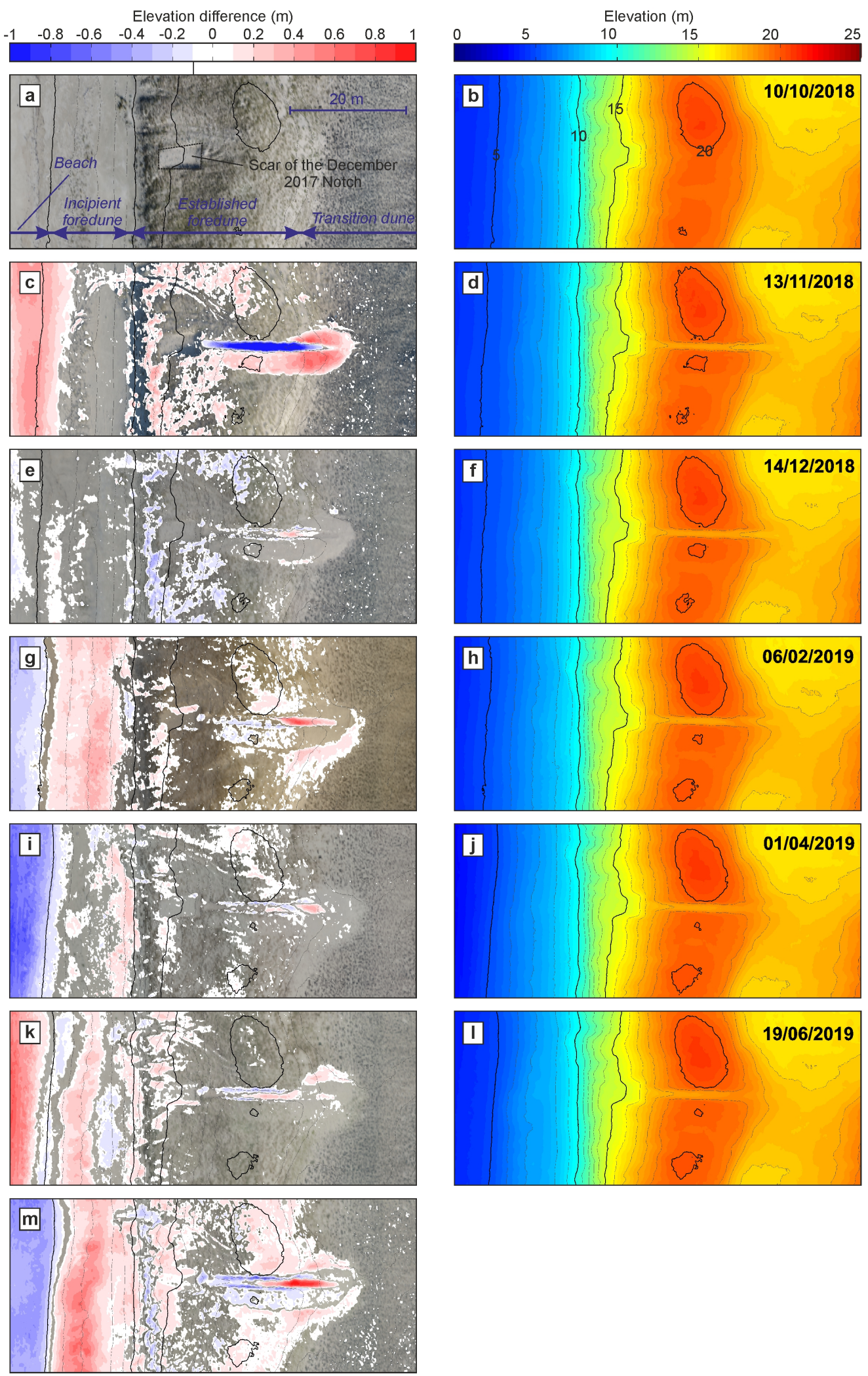

Figure 7. (Right-hand panels): DEM of the coastal dune zoomed onto an elongated excavated in the foredune in early November 2018. (Left-hand panels): corresponding orthophoto and superimposed elevation difference between two consecutive surveys. (m) Orthophoto of 19 June 2019 with superimposed elevation difference between 9 June 2019 and 11 November 2018 just after the notch was excavated. 

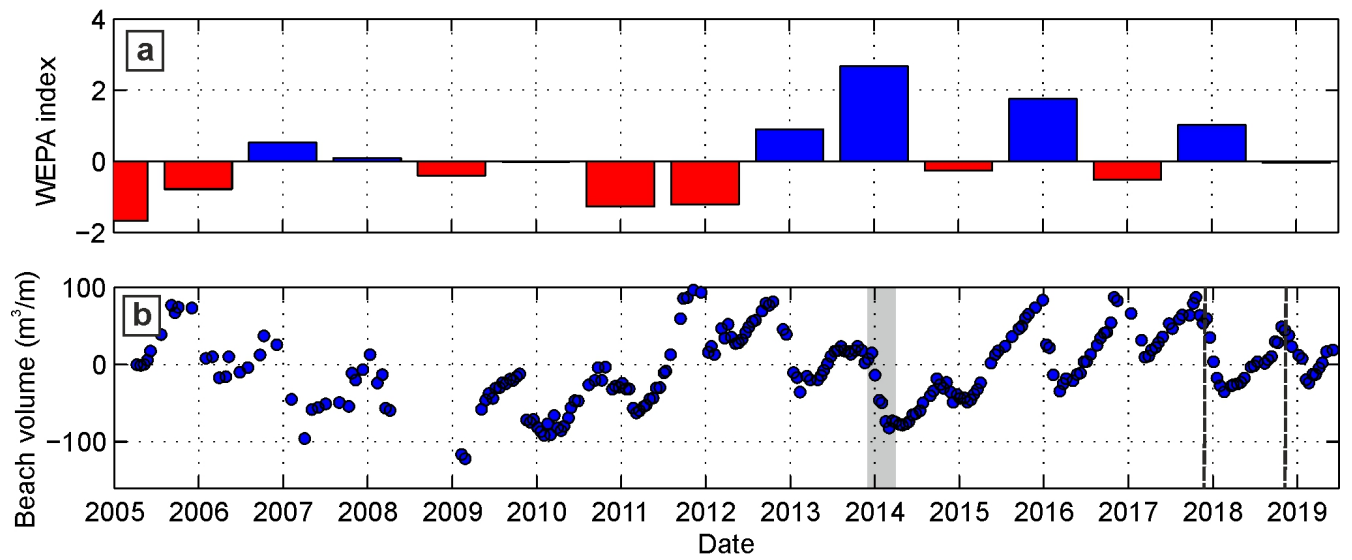

Figure 8. 2005-2019 time series of (a) winter WEPA and (b) alongshore-averaged beach volume computed between the $0 \mathrm{~m}$ and $6 \mathrm{~m}$ elevation contours, with the light grey area indicating the outstanding winter of 2013/2014. In panel (b), the vertical black dashed lines indicate when the experimental notches were excavated in December 2017 and November 2018.
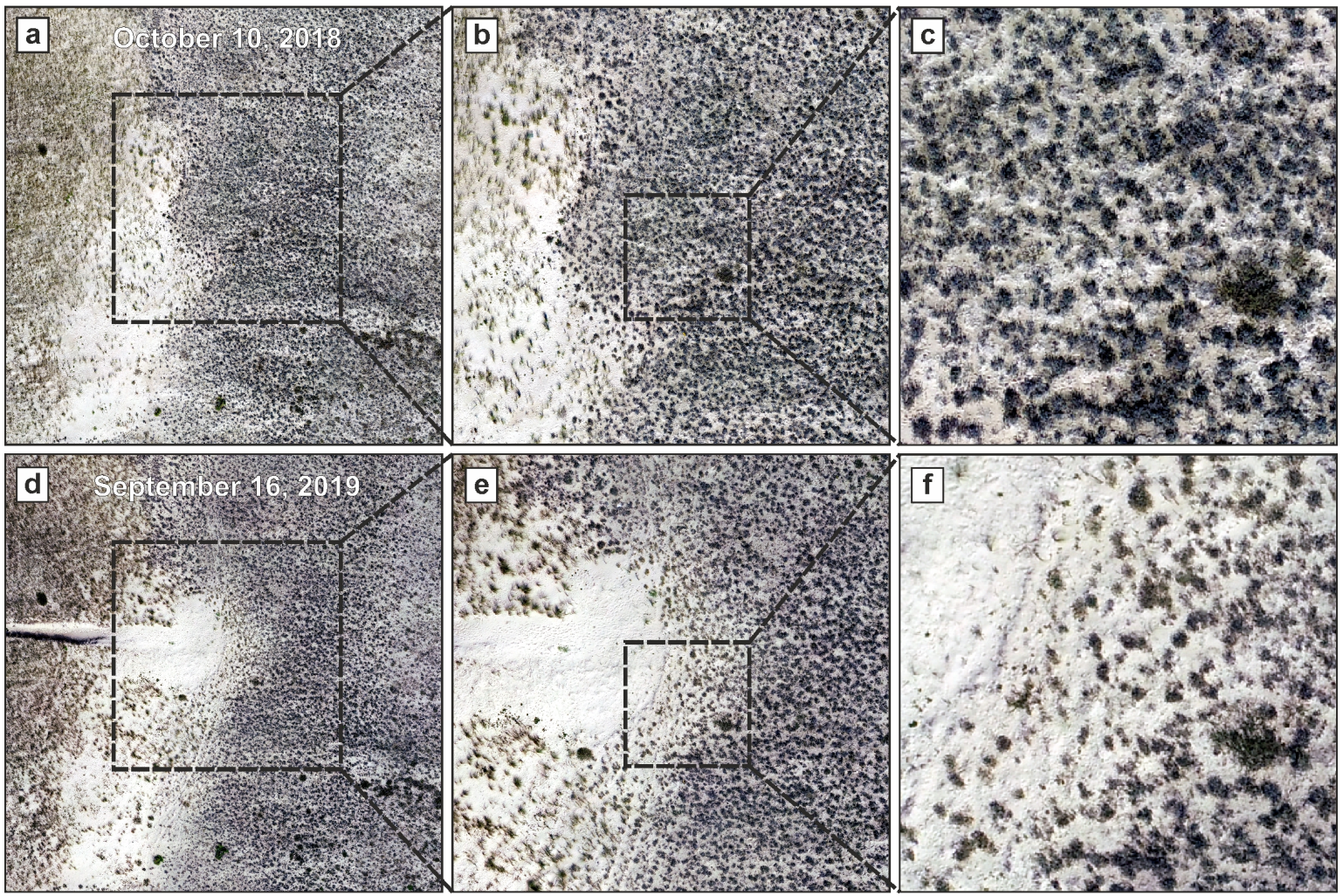

Figure 9. Aerial photographs and progressive zoom showing vegetation landscape $(\mathbf{a}-\mathbf{c})$ before (10 October 2018) and (d-f) approximately 10 months (16 September 2019) after an established foredune notch has been excavated (Ph. Q. Laporte-Fauret).

\section{Discussion and Conclusions}

Approximately two years after the first notches were excavated, preliminary results indicate that the notches excavated in both the incipient and established foredune showed limited morphological development. They mostly infilled, with sometimes slight vegetation regrowth, indicating the dominance of biotic processes on abiotic processes [35]. Only the large elongated notches excavated in the established foredune in November 2018 showed evidence of development. Although the number of coastal dune experiments involving excavated notches are limited worldwide, some experiments also showed limited performance although infilling took generally more time. For instance, the authors 
of [36] observed that a single 60-m-wide notch in the foredune at a Dutch beach rapidly infilled with the wind-blown sand. After three years, aeolian processes decreased in intensity together with vegetation regrowth resulting in the partial closure of the notch. Similar observations were made after the restoration of some blowouts in the Netherlands [12,37]. Although such a decrease in aeolian dynamics typically takes a few years, other studies show large development of excavated notches. The authors of [38] monitored 27 notches along the Welsh coast. They showed that the most active notches face wide and high beaches, have a convex floor or tend to narrow landward. More recently, the authors of [39] examined the evolution of five massive notches excavated in the foredune of the Dutch National Park Zuid-Kennemerland. Notches were 50-100-m-wide, 100-200-m-long and 9-12.5-m-deep. The notches were found to cause $75 \%$ of the sand to be deposited landward of the foredune, highlighting that these notches are highly effective conduits for aeolian landward transport. Large morphological changes were also observed, in line with the typical natural trough blowout growth stage, see, e.g., [40]. At Truc Vert, except for the notches excavated in the established foredune in November 2018, the combination of moderate winter wind conditions and the short dimensions of the notches can explain why they did not transform into blowouts. The authors of [39] also observed that some of the notches did not well develop the first year. In addition, some morphological patterns (U-shape cross section, erosion of the seaward part of the floor, retreat of the lateral walls and growth of the depositional lobe) indicate that the elongated notches excavated in the established foredune are in a natural trough blowout growth stage, also referred to as geomorphological stage in [35], when abiotic processes dominate. Therefore, we anticipate that a stormy winter may cause the elongated notches excavated in the established foredune to further develop. Clearly, such development will strongly depend on the interannual variability in storm activity. In addition, the interannual variability in vegetation dynamics could also affect blowout growth. However, vegetation surveys started less than two years ago and are insufficient to date to draw definitive conclusions. The detailed monitoring of the coastal dune over the next years will provide more insight into the development of excavated notches in this region of the Atlantic coast of Europe.

Reinstating natural processes does not necessarily mean nature restoration [41], and increased landscape diversity does not necessarily imply an overall increased plant and animal species diversity. At this stage, the area of bare sand landward of the elongated notches increased and the notch floor remained nonvegetated, implying a loss of vegetation cover. Given the timescales involved in the restoration of coastal dunes, long-term (years to decades) monitoring of the coastal dune of Truc Vert will be required to elucidate whether the reinstatement of natural processes and beach-dune sediment exchange triggered by the elongated notches can further increase (1) the landward dune migration rate and (2) the overall higher vegetation and animal species diversity. Alternatively, we can examine coastal dunes in Southwest France that have not been reprofiled and managed by the coastal dune stakeholders. The most relevant example is the coastal dune system of Trencat in the south of the Gironde coast (Figure 3a). Trencat has been a restricted military area for more than 40 years and no management has been performed since then. Figure 10 highlights the contrasting landscape and morphology of the coast between the managed and the non-managed sectors of Trencat. Consistent with the right-hand panels in Figure 2, the coastal dune migrated downwind by more than $100 \mathrm{~m}$ into the forest. However, the majority of the dune system is now made of bare sand, suggesting a decrease of vegetation and animal species diversity. The coastal dune in the non-managed sector is twice as wide and slightly higher than that in the managed sector. This may suggest that, in this region of the Atlantic coast of Europe, more mobile coastal dunes accommodate erosion by translating inland but exhibit reduced biodiversity, consistent with the findings in [16]. Future work is required to test this hypothesis and explore its sensitivity to local sediment budget and chronic erosion trends. In future years, vegetation monitoring, aeolian sand transport measurements and morphological surveys at Truc Vert, and at other coastal dune settings in Southwest France, will provide more insight into the influence of natural processes reinstatement on overall coastal dune response and resilience. 


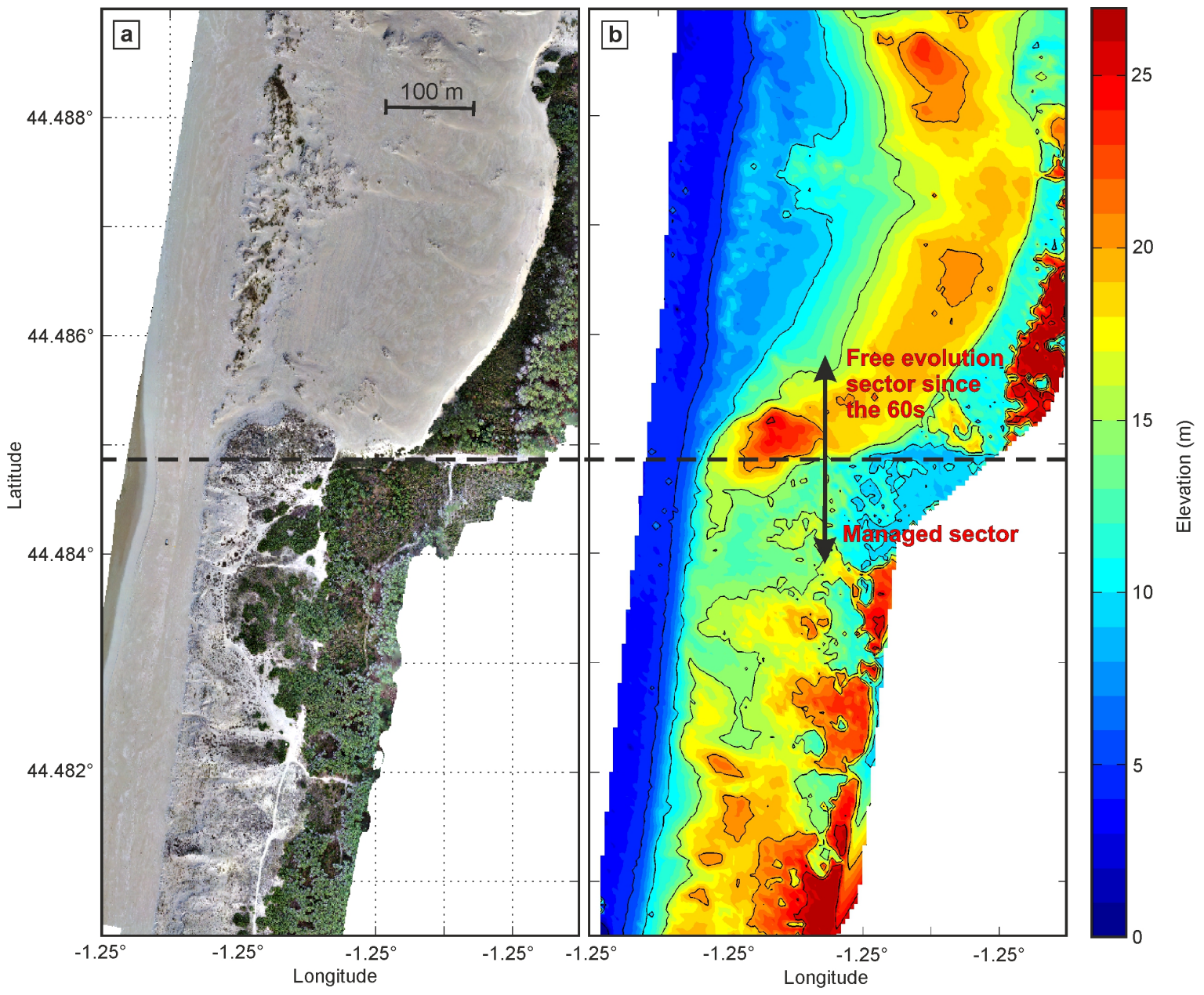

Figure 10. (a) Orthophoto and (b) DSM of the coastal dune at Trencat Photo and DEM of the coastal dune at Trencat. In both panels, the thick dashed line indicate the separation between the managed sector in the south and the northern sector which has not been managed since the 1960s.

Author Contributions: Conceptualisation, B.C.; methodology, Q.L.-F., V.M., R.M., B.C., D.R. and S.B.; validation, Q.L.-F.; investigation, Q.L.-F., V.M., R.M. and B.C.; writing-original draft preparation, B.C. and Q.L.-F.; writing-review and editing, all authors; project administration, B.C.; funding acquisition, B.C.

Funding: This research was funded by Agence Nationale de la Recherche (ANR) grant number ANR-17CE01-0014.

Acknowledgments: This study includes the monitoring study site of Truc Vert labelled by the Service National d'Observation (SNO) Dynalit (https://www.dynalit.fr), which also provides a framework for the long-term shoreline monitoring of the entire Gironde coast. The Observatoire Aquitaine de l'Univers (OASU) and Observatoire de la Côte Aquitaine (OCA) provide additional support for the surveys with OCA also providing the Lidar data.

Conflicts of Interest: The authors declare no conflicts of interest. 


\section{Abbreviations}

The following abbreviations are used in this manuscript.

$\begin{array}{ll}\text { ATV } & \text { All-terrain vehicle } \\ \text { DEM } & \text { Digital elevation model } \\ \text { DGPS } & \text { Differential global positioning system } \\ \text { DSM } & \text { Digital surface model } \\ \text { ONF } & \text { Office National des Forêts } \\ \text { UAV } & \text { Unmanned Aerial Vehicle } \\ \text { WEPA } & \text { West Europe Pressure Anomaly }\end{array}$

\section{References}

1. Mentaschi, L.; Vousdoukas, M.; Pekel, J.F.; Voukouvalas, E.; Feyen, L. Global long-term observations of coastal erosion and accretion. Sci. Rep. 2018, 8. doi:10.1038/s41598-018-30904-w. [CrossRef] [PubMed]

2. Seto, K.; Fragkias, M.; Güneralp, B.; Reilly, M. A meta-analysis of global urban land expansion. PLoS ONE 2011, 6. doi:10.1371/journal.pone.0023777. [CrossRef] [PubMed]

3. Cazenave, A.; Nerem, R.S. Present-day sea level change: Observations and causes. Rev. Geophys. $2004,42$. doi:10.1029/2003RG3001. [CrossRef]

4. Zappa, G.; Shaffrey, L.C.; Hodges, K.I.; Sansom, P.G.; Stephenson, D.B. A Multimodel Assessment of Future Projections of North Atlantic and European Extratropical Cyclones in the CMIP5 Climate Models. J. Clim. 2013, 26, 5846-5862. doi:10.1175/JCLI-D-12-00573.1. [CrossRef]

5. Temmerman, S.; Meire, P.; Bouma, T.J.; Herman, P.M.J.; Ysebaert, T.; De Vriend, H.J. Ecosystem-based coastal defence in the face of global change. Nature 2013, 504, 79-83. doi:10.1038/nature12859. [CrossRef] [PubMed]

6. Ferrario, F.; Beck, M.; Storlazzi, C.; Micheli, F.; Shepard, C.; Airoldi, L. The effectiveness of coral reefs for coastal hazard risk reduction and adaptation. Nature 2014, 5. doi:10.1038/ncomms4794. [CrossRef]

7. Bouvier, C.; Castelle, B.; Balouin, Y. Modeling the Impact of the Implementation of a Submerged Structure on Surf Zone Sandbar Dynamics. J. Mar. Sci. Eng. 2019, 7. doi:10.3390/jmse7040117. [CrossRef]

8. de Schipper, M.A.; de Vries, S.; Ruessink, G.; de Zeeuw, R.C.; Rutten, J.; van Gelder-Maas, C.; Stive, M.J. Initial spreading of a mega feeder nourishment: Observations of the Sand Engine pilot project. Coastal Eng. 2016, 111, 23-38. doi:10.1016/j.coastaleng.2015.10.011. [CrossRef]

9. Luijendijk, A.; Hagenaars, G.; Ranasinghe, R.; Baart, F.; Donchyts, G.; Aarninkhof, S. The State of the World's Beaches. Sci. Rep. 2018, 8. doi:10.1038/s41598-018-24630-6. [CrossRef]

10. Moyle, P.; Leidy, R. Loss of Biodiversity in Aquatic Ecosystems: Evidence from Fish Faunas. In Conservation Biology; Fiedler, P.L., Jain, S.K., Eds.; Springer: Boston, MA, USA, 1992.

11. Daily, G. Restoring value to the world's degraded lands. Science 1995, 269, 350-354. doi:10.1126/science.269.5222.350. [CrossRef]

12. Arens, S.; Mulder, J.; Slings, Q.; Geelen, L.; Damsma, P. Dynamic dune management, integrating objectives of nature development and coastal safety: Examples from the Netherlands. Geomorphology 2013, 199, 205-213. doi:10.1016/j.geomorph.2012.10.034. [CrossRef]

13. Nordstrom, K.F. Coastal Dunes. In Coastal Environments and Global Change; Masselink, G., Gehrels, R., Eds.; John Wiley \& Sons, Ltd.: Hoboken, NJ, USA, 2015; pp. 178-193.doi:10.1002/9781119117261.ch8. [CrossRef]

14. Martinez, M.; Hesp, P.; Gallego-Fernandez, J. Coastal dunes: human impact and need for restoration. In Restoration of Coastal Dunes; Martinez, M., Gallego-Fernandez, J.B., Hesp, P., Eds.; Springer: Berlin, Germany, 2013; pp. 1-4.

15. Heslenfeld, P.; Jungerius, P.; Klijn, J. European coastal dunes: Ecological values, threats, opportunities and policy development. In Coastal Dunes, Ecology and Conservation; Martinez, M., Pusty, N., Eds.; Springer: Berlin, Germany, 2004; pp. 335-351.

16. Houston, M. A general hypothesis of species diversity. Am. Nat. 1979, 113, 81-101. [CrossRef]

17. Michalet, R.; Maalouf, J.P.; Choler, P.; Clément, B.; Rosebery, D.; Royer, J.; Schöb, C.; Lortie, C. Competition, facilitation and environmental severity shape the relationship between local and regional species richness in plant communities. Ecography 2015, 38, 335-345. [CrossRef] 
18. Forey, E.; Touzard, B.; Michalet, R. Does disturbance drive the collapse of biotic interactions at the severe end of a diversity-biomass gradient? Plant Ecol. 2010, 206, 287-295. [CrossRef]

19. Nordstrom, K.; Lampe, R.; Jackson, N. Increasing the dynamism of coastal landforms by modifying shore protection methods: Examples from the eastern German Baltic Sea Coast. Environ. Conserv. 2007, 34, $205-214$. doi:10.1017/S037689290700416X. [CrossRef]

20. Castelle, B.; Guillot, B.; Marieu, V.; Chaumillon, E.; Hanquiez, V.; Bujan, S.; Poppeschi, C. Spatial and temporal patterns of shoreline change of a 280-km high-energy disrupted sandy coast from 1950 to 2014: SW France. Estuar. Coast. Shelf Sci. 2018, 200, 212 -223. doi:10.1016/j.ecss.2017.11.005. [CrossRef]

21. Castelle, B.; Bujan, S.; Ferreira, S.; Dodet, G. Foredune morphological changes and beach recovery from the extreme 2013/2014 winter at a high-energy sandy coast. Mar. Geol. 2017, 385, 41-55. doi:10.1016/j.margeo.2016.12.006. [CrossRef]

22. Masselink, G.; Castelle, B.; Scott, T.; Dodet, G.; Suanez, S.; Jackson, D.; Floc'h, F. Extreme wave activity during 2013/2014 winter and morphological impacts along the Atlantic coast of Europe. Geophys. Res. Lett. 2016, 43, 2135-2143. doi:10.1002/2015GL067492. [CrossRef]

23. Castelle, B.; Dodet, G.; Masselink, G.; Scott, T. A new climate index controlling winter wave activity along the Atlantic coast of Europe: The West Europe Pressure Anomaly. Geophys. Res. Lett. 2017, 44, 1384-1392. doi:10.1002/2016GL072379. [CrossRef]

24. Castelle, B.; Dodet, G.; Masselink, G.; Scott, T. Increased Winter-Mean Wave Height, Variability, and Periodicity in the Northeast Atlantic Over 1949-2017. Geophys. Res. Lett. 2018, 45, 3586-3596. doi:10.1002/2017GL076884. [CrossRef]

25. Idier, D.; Castelle, B.; Charles, E.; Mallet, C. Longshore sediment flux hindcast: spatio-temporal variability along the SW Atlantic coast of France. J. Coast. Res. 2013, 65, 1785-1790. [CrossRef]

26. Castelle, B.; Marieu, V.; Bujan, S.; Splinter, K.D.; Robinet, A.; Senechal, N.; Ferreira, S. Impact of the winter 2013-2014 series of severe Western Europe storms on a double-barred sandy coast: Beach and dune erosion and megacusp embayments. Geomorphology 2015, 238, 135-148. [CrossRef]

27. Lerma, A.N.; Ayache, B.; Ulvoas, B.; Paris, F.; Bernon, N.; Bulteau, T.; Mallet, C. Pluriannual beach-dune evolutions at regional scale: Erosion and recovery sequences analysis along the aquitaine coast based on airborne LiDAR data. Cont. Shelf Res. 2019, 189, 103974. doi:10.1016/j.csr.2019.103974. [CrossRef]

28. Castelle, B.; Marieu, V.; Bujan, S. Alongshore-variable beach and dune changes on the timescales from days (storms) to decades along the rip-dominated beaches of the Gironde Coast. In Coastal Evolution under Climate Change along the Tropical Overseas and Temperate Metropolitan France; Castelle, B., Chaumillon, E., Eds.; Coastal Education \& Research Foundation (CERF): Coconut Creek, FL, USA, 2019; pp. 157-171. doi:10.2112/SI88-012.1. [CrossRef]

29. Barrère, P. Dynamics and management of the coastal dunes of the Landes, Gascony, France. Coastal Dunes: geomorphology, ecology and management for conservation. In Proceedings of the 3rd European Dune Congress , Galway, Ireland, 17-21 June 1992; Carter, R.W.G., Curtis, T.G.F., Sheehy-Skeffington, M.J., Eds.; 1992; pp. 25-32.

30. Prat, M.; Auly, T. L'évolution du littoral médocain à Lacanau. Sud-Ouest Européen 2010, 29, 53-64. [CrossRef]

31. Narteau, C.; Zhang, D.; Rozier, O.; Claudin, P. Setting the length and time scales of a cellular automaton dune model from the analysis of superimposed bed forms. J. Geophys. Res. 2009, 114. doi:10.1029/2008JF001127. [CrossRef]

32. Castelle, B.; Marieu, V.; Bujan, S.; Ferreira, S.; Parisot, J.P.; Capo, S.; Senechal, N.; Chouzenoux, T. Equilibrium shoreline modelling of a high-energy meso-macrotidal multiple-barred beach. Mar. Geol. 2014, 347, 85-94. [CrossRef]

33. Laporte-Fauret, Q.; Marieu, V.; Castelle, B.; Michalet, R.; Bujan, S.; Rosebery, D. Low-Cost UAV for High-Resolution and Large-Scale Coastal Dune Change Monitoring Using Photogrammetry. J. Mar. Sci. Eng. 2019, 7. doi:10.3390/jmse7030063. [CrossRef]

34. Laporte-Fauret, Q.; Alonso Ayuso, A.T.; Rodolfo-Damanio, T.; Marieu, V.; Castelle, B.; Bujan, S.; Rosebery, D.; Michalet, R. The role of physical disturbance for ecosystem functioning in coastal sand dunes. J. Ecol. Submitted.

35. Schwarz, C.; Brinkkemper, J.; Ruessink, G. Feedbacks between biotic and abiotic processes governing the development of foredune blowouts: A review. J. Mar. Sci. Eng. 2018, 7. doi:10.3390/jmse7010002. [CrossRef] 
36. Meerkerk, A.; Arens, S.; van Lammeren, R.; Stuiver, H. Sand transport dynamics after a foredune breach: A case study from Schoorl, The Netherlands. Geomorphology 2007, 86, 52-60. doi:10.1016/j.geomorph.2006.08.007. [CrossRef]

37. Arens, S.; Geelen, L. Dune landscape rejuvenation by intended destabilisation in the Amsterdam Water Supply Dunes. J. Coast. Res. 2006, 225, 1094-1107. [CrossRef]

38. Pye, K.; Blott, S.J. Dune Rejuvenation Trials: Overview Report; Report to Natural Resources Wales. Tech. Rep. KPAL Report 19099; Kenneth Pye Associates Ltd.: Reading, UK, 2016.

39. Ruessink, B.; Arens, S.; Kuipers, M.; Donker, J. Coastal dune dynamics in response to excavated foredune notches. Aeolian Res. 2018, 31,3-17. doi:10.1016/j.aeolia.2017.07.002. [CrossRef]

40. Hesp, P.A. Foredunes and blowouts: initiation, geomorphology and dynamics. Geomorphology 2002, 48, 245-268. [CrossRef]

41. Delgado-Fernandez, I.; Davidson-Arnott, R.G.D.; Hesp, P.A. Is 're-mobilisation' nature restoration or nature destruction? A commentary. J. Coast. Conserv. 2019. doi:10.1007/s11852-019-00716-9. [CrossRef]

(C) 2019 by the authors. Licensee MDPI, Basel, Switzerland. This article is an open access article distributed under the terms and conditions of the Creative Commons Attribution (CC BY) license (http:/ / creativecommons.org/licenses/by/4.0/). 